\title{
Kualitas Fisik, Kimia dan Mikrobiologi Susu Kambing pada Waktu Pemerahan yang Berbeda di Peternakan Cangkurawok, Balumbang Jaya, Bogor
}

\author{
Physical Quality, Chemical, and Microbiology on Goat's Milk in Different Milking Time in \\ Cangkorawok Farm, Balumbang Jaya, Bogor \\ M. Arifin, A. Y. Oktaviana, R. R. S. Wihansah, M. Yusuf, Rifkhan, J. K. Negara, A. K. Sio \\ Mahasiswa Sekolah Pascasarjana, Departemen Ilmu Produksi dan Teknologi Peternakan \\ Fakultas Peternakan, Institut Pertanian Bogor \\ Email : thtseru@gmail.com
}

\begin{abstract}
The aim of this study was to determine the physical, chemistry, and microbiological quality of goat's milk collected from morning and afternoon milking. A total of 3 of crossbred goat (PE) milk were used in this study. These samples were analyzed for total plate count (TPC), Staphylococcus sp, Escherichia coli, and Salmonella sp. Test anova shown any significant differences $(\mathbf{p}<0.05)$ in Escherichia coli while another microorganisms not significant. For quality physical and chemical anova results showed no difference between morning and afternoon milking. Based on Indonesian National Standard (SNI) for fresh milk No 3141.1-2011, the level of TPC, and Salmonella sp.were still in standard range, while Staphylococcus sp.and Escherichia coli was exceed the standard value. In conclusion, raw milk of goat collected directly from the udder is safe to consume.
\end{abstract}

Keywords: chemistry, goat's milk, microbiological quality test, the physical

PENDAHULUAN

Susu kambing telah dikenal dan dipercaya masyarakat memiliki manfaat yang baik untuk kesehatan tubuh karena susu banyak mengandung nutrisi dan komponen bioaktif yang berperan menjaga kesehatan tubuh. Namun susu mudah rusak oleh beberapa bakteri yang memanfaatkan kandungan nutrisi susu sebagai media pertumbuhannya, seperti Escherichia coli, Salmonella sp., dan Staphylococcus aureus, oleh karena itu, perlu jaminan kualitas susu yang dimulai dari peternakan sampai ke tangan konsumen. Jaminan keamanan susu telah menjadi tuntutan masyarakat seiring dengan meningkatnya status sosial. Selain hal tersebut, tanpa adanya jaminan keamanan, maka akan sulit memastikan kualitas susu yang dihasilkan.

Salah satu hal yang dapat mempengaruhi kualitas susu adalah interval pemerahan. Pemerahan susu biasanya dilakukan 2 kali sehari yaitu pagi dan sore hari. Interval waktu yang sama antara pemerahan pagi dan sore hari akan memberikan perubahan komposisi susu yang relatif sedikit, sedangkan interval waktu pemerahan yang berbeda akan menghasilkan komposisi susu yang berbeda juga (Sudono 1985). Selain itu faktor lingkungan berupa temperatur suhu kandang yang berbeda antara pagi dan sore hari dapat juga mempengaruhi mikrobiologis yang terkandung didalam susu hasil pemerahan sehingga perlu adanya pengujian kualitas fisik, kimia, dan mikrobiologi susu kambing segar pada waktu pemerahan yang berbeda yang kemudian dibandingkan dengan standar yang berlaku sehingga aman untuk dikonsumsi.

\section{MATERI DAN METODE}

\author{
Alat dan Bahan \\ Bahan yang digunakan adalah susu kambing
} segar yang diperoleh dari peternakan Cangkurawok, Balumbang jaya, Bogor. Bahan untuk uji mikrobiologis menggunakan plate count agar (PCA), eosin methylene blue agar (EMBA), buffer pepton agar (BPA), dan xylose lysine deoxycholate agar (XLDA). Pengujian mikrobiologi dan Fisik susu dilakukan di Laboratorium Terpadu Fakultas Peternakan Institut Pertanian Bogor. Uji kualitas kimia susu menggunakan milkotester dilakukan di laboratoriun ternak perah Fakultas Peternakan Institut Pertanian Bogor.

Prosedur Pengambilan Susu

Susu kambing sebagai sampel berasal dari induk laktasi produktif sebanyak 3 ekor yang diambil pada hari yang berbeda. Sampel susu diambil sebanyak $500 \mathrm{ml}$. Sampel ditempatkan pada wadah plastik kemudian disimpan pada cooling box. Sampel segera dibawa ke laboratorium untuk dianalisis.

\section{Peubah yang diamati}

Peubah yang diamati pada penelitian ini adalah sifat fisik yaitu $\mathrm{pH}$, berat jenis dan $\mathrm{a}_{\mathrm{w}}$, sifat kimia susu segar yaitu bahan kering, kadar protein, kadar lemak. Sifat mikrobiologi yaitu total plate count (TPC), Escherichia coli, Salmonella sp, dan staphylococus aureus.

Penghitungan Total Plate Count (TPC)

Penghitungan TPC menggunakan metode SNI 2897:2008. Sebanyak $25 \mathrm{ml}$ susu dimasukkan ke dalam wadah steril yang sudah berisi $225 \mathrm{ml}$ larutan buffer peptone 
water (BPW) 0,1\% steril, kemudian dihomogenkan selama 1 menit sampai dengan 2 menit ini merupakan larutan dengan pengenceran $10^{-1}$. Sebanyak $1 \mathrm{ml}$ pengenceran $10^{-1}$ diambil kemudian diencerkan menggunakan BPW $9 \mathrm{ml}$ sebagai pengeceran $10^{-2}$, lalu diulangi lagi sampai dengan pengenceran $10^{-5}$. Selanjutnya dari masing-masing pengenceran diambil $1 \mathrm{ml}$ untuk dimasukkan ke dalam cawan petri steril secara duplo, kemudian dituang media cair plate count agar (PCA) sebanyak $20 \mathrm{ml}$ dan dihomogenkan dengan cara menggeserkan cawan horizontal atau membentuk angka delapan dan dibiarkan menjadi padat. Tahap selanjutnya diinkubasikan pada suhu $37^{\circ} \mathrm{C}$ selama 24-48 jam, dan semua koloni yang tumbuh dihitung sebagai TPC dengan metode Bacteriological Analytical Manual (BAM) (FDA 2001).

\section{Pemeriksaan Escherichia coli}

Sebanyak $25 \mathrm{ml}$ susu dimasukkan ke dalam wadah steril yang sudah berisi $225 \mathrm{ml}$ larutan buffer peptone water (BPW) 0,1\% steril, kemudian dihomogenkan selama 1 menit sampai dengan 2 menit ini merupakan larutan dengan pengenceran $10^{-1}$. Sebanyak $1 \mathrm{ml}$ pengenceran $10^{-1}$ diambil kemudian diencerkan menggunakan BPW $9 \mathrm{ml}$ sebagai pengeceran $10^{-2}$, lalu diulangi lagi sampai dengan pengenceran $10^{-5}$. Selanjutnya dari masingmasing pengenceran diambil $1 \mathrm{ml}$ untuk dimasukkan ke dalam cawan petri steril secara duplo, kemudian dituang media eosin methylene blue agar (EMBA) (Oxoid Ltd., Basingstoke, United Kingdom) dan diinkubasikan pada suhu $37^{\circ} \mathrm{C}$ selama 24 jam.

\section{Pemeriksaan Salmonella sp}

Penghitungan Salmonella sp. mengguna-kan metode SNI 2897:2008. Sebanyak $25 \mathrm{ml}$ susu dimasukkan ke dalam wadah steril yang sudah berisi $225 \mathrm{ml}$ larutan buffer peptone water (BPW)0,1 \% steril, kemudian dihomogenkan selama 1 menit sampai dengan 2 menit ini merupakan larutan dengan pengenceran $10^{-1}$. Sebanyak $1 \mathrm{ml}$ pengenceran $10^{-1}$ diambil kemudian diencerkan menggunakan BPW $9 \mathrm{ml}$ sebagai pengeceran $10^{-2}$, lalu diulangi lagi sampai dengan pengenceran $10^{-3}$. Selanjutnya dari masing-masing pengenceran diambil $1 \mathrm{ml}$ untuk dimasukkan ke dalam cawan petri steril secara duplo, kemudian dituang media xylose lysine deoxycholate agar (XLD) (Oxoid Ltd., Basingstoke, United Kingdom) dan diinkubasikan pada suhu $37^{\circ} \mathrm{C}$ selama 24 jam. Koloni yang tumbuh dihitung dengan metode Bacteriological Analytical Manual (BAM) (FDA, 2001).

\section{Pemeriksaan Staphylococus aureus sp.}

Penghitungan menggunakan metode SNI 2897:2008. Sebanyak $25 \mathrm{ml}$ susu dimasukkan ke dalam wadah steril yang sudah berisi $225 \mathrm{ml}$ larutan buffer peptone water (BPW)0,1 \% steril, kemudian dihomogenkan selama 1 menit sampai dengan 2 menit ini merupakan larutan dengan pengenceran $10^{-1}$. Sebanyak $1 \mathrm{ml}$ pengenceran $10^{-1}$ diambil kemudian diencerkan menggunakan BPW $9 \mathrm{ml}$ sebagai pengeceran $10^{-2}$, lalu diulangi lagi sampai dengan pengenceran $10^{-3}$. Selanjutnya dari masing-masing pengenceran diambil $1 \mathrm{ml}$ untuk dimasukkan ke dalam cawan petri steril secara duplo, kemudian dituang media BPA sebanyak $15 \mathrm{ml}$ sampai dengan $20 \mathrm{ml}$ media yang sudah ditambah dengan egg yolktellurite emulsion $(5 \mathrm{ml} \mathrm{ke}$ dalam $95 \mathrm{ml}$ media BPA) pada masing-masing cawan yang akan digunakan sampai memadat.

Pipet $0,1 \mathrm{ml}$ suspensi dari setiap pengenceran, dan diinokulasikan masing-masing pada cawan petri yang berisi media BPA yang sudah memadat. Suspensi diratakan di atas permukaan media agar dengan menggunakan batang gelas (hockey stick) sampai suspensi terserap. Lalu diinkubasi pada temperatur $37^{\circ} \mathrm{C}$ selama 24 jam. Koloni yang tumbuh dihitung dengan metode Bacteriological Analytical Manual (BAM) (FDA, 2001).

\section{Rancangan Percobaan}

Rancangan perlakuan yang digunakan adalah 1 faktor yaitu waktu pemerahan, dengan 2 taraf yaitu pemerahan pagi hari pada pukul 08.00 WIB dan sore hari pada pukul 15.00 WIB. Rancangan lingkungan yang digunakan adalah Rancangan Acak Kelompok Lengkap (RAKL) dengan kelompok menggunakan hari yang berbeda. Data diolah dengan analisis ragam, Analysis of variance (ANOVA), menggunakan program statistik Minitab 16 (Mattjik dan I Made 2013).

\section{HASIL DAN PEMBAHASAN}

\section{Kualitas Mikrobiologis}

Kualitas mikrobiologis susu kambing segar mengacu pada SNI No. 01-3141-2011 susu segar sapi karena pemerintah belum menetapkan standar untuk susu kambing segar. Perbedaan waktu pemerahan terhadap TPC menunjukkan hasil yang tidak berbeda nyata antara susu pagi dan susu sore. Kandungan total mikroba (total plate count) dari kedua waktu pemerahan tersebut masih memenuhi persyaratan SNI, yaitu 1 x $10^{6} \mathrm{CFU} / \mathrm{ml}$, atau $\log 6 \mathrm{cfu} / \mathrm{ml}$ (BSN 2011). Standar TPC susu kambing segar menurut EU Council Directive 92/46/EEC (EC 1992) adalah 1,65 x $10^{3}$ atau 3,2 $\log _{10} \mathrm{cfu} / \mathrm{ml}$. Meskipun tidak berbeda nyata, kandungan TPC susu pagi secara deskriptif lebih tinggi dibandingkan dengan susu sore. Perbedaan jumlah TPC kemungkinan disebabkan karena perbedaan dalam sanitasi kandang, peralatan dan pemerahan (Cahyono et al. 2013). Kondisi kandang saat pagi hari terdapat kotoran ternak yang lebih banyak daripada di siang hari karena peternak hanya membersihkan kandang 1 kali sehari pada pagi hari, sehingga banyak kotoran yang menumpuk di pagi hari. Peralatan dapat menjadi sumber kontaminasi apabila tidak dibersihkan secara maksimal terutama bagian yang kontak langsung dengan susu.

Tabel 1 Kualitas mikrobiologi susu kambing

\begin{tabular}{lcc}
\hline Bakteri & Susu Pagi $(\mathrm{cfu} / \mathrm{ml})$ & Susu Sore $(\mathrm{cfu} / \mathrm{ml})$ \\
\hline TPC & $5,54 \pm 0,59 \mathrm{a}$ & $4,97 \pm 0,41$ \\
Escherichia coli & $2,19 \pm 0,69 \mathrm{a}$ & $<1 \mathrm{~b}$ \\
Salmonella $\mathrm{sp}$. & $<1$ & $<1$ \\
Staphylococus & $2,56 \pm 0,20$ & $2,52 \pm 0,16$ \\
aureus & & \\
\hline
\end{tabular}

Keterangan : Superskrip yang berbeda pada baris yang sama menunjukkan berbeda nyata pada taraf $5 \%(\mathrm{P}<0,05)$ 
Perbedaan temperatur dan kelembaban juga dapat mempengaruhi total mikroba susu karena pada pagi hari umumnya suhu lebih rendah dengan kelembaban yang lebih tinggi dibanding sore hari (Tabel 2). Kondisi tersebut dapat membantu pertumbuhan mikroba. Hal ini sesuai dengan Gaman dan Sherrington (1994) menjelaskan bahwa yang mempengaruhi pertumbuhan bakteri adalah waktu, pakan, kelembaban, suhu, oksigen, dan $\mathrm{pH}$

Tabel 2 Suhu dan kelembaban kandang

\begin{tabular}{lcccc}
\hline Hari ke & \multicolumn{2}{c}{ Pagi } & \multicolumn{2}{c}{ Sore } \\
\cline { 2 - 5 } & Suhu $\left({ }^{\circ} \mathrm{C}\right)$ & $\mathrm{Rh}(\%)$ & Suhu $\left({ }^{\circ} \mathrm{C}\right)$ & $\mathrm{Rh}(\%)$ \\
\hline H 1 & 27 & 82 & 29 & 80 \\
H 2 & 28 & 84 & 30 & 80 \\
H 3 & 29 & 85 & 29 & 82 \\
\hline
\end{tabular}

Pengujian jumlah Escherichia coli pada susu kambing segar menunjukan hasil yang berbeda nyata antara susu pagi dan sore hari. Susu pagi ditemukan adanya Escherichia coli sedangkan susu sore tidak ditemukan adanya Escherichia coli. Standar European Council (EC 1992) untuk Escherichia coli adalah negatif sehingga susu pagi tidak memenuhi persyaratan EC. Tingginya jumlah koloni Escherichia coli pada pemerahan pagi kemungkinan dipengaruhi oleh kebersihan sanitasi dan hygiene tangan peternak dalam melakukan pemerahan susu karena pemerahan dilakukan setelah melakukan sanitasi kandang. Jika sanitasi tangan tidak dilakukan dengan baik maka akan menyebabkan sumber kontamintasi terhadap susu segar. Hal ini sesuai dengan Vimont et al. (2006) yang menyatakan bahwa kontiminasi Escherichia coli, sebagian besar disebabkan karena peternak kurang memperhatikan kebersihan sanitasi dan hygiene personal. Kemungkinan pencemaran lainnya disebabkan oleh daerah buangan feses yang masih berdekatan dengan kandang, sehingga ketika dilakukan pemerahan mikroorganisme dapat masuk melalui debu yang dibawa oleh angin.

Staphylococcus aureus yang terdapat dalam susu segar pemerahan pagi dan sore hari menunjukkan hasil yang tidak berbeda nyata, namun masih melebihi standar yang ditetapkan oleh SNI yaitu $1 \times 10^{2}$ atau $2 \log _{10} \mathrm{cfu} / \mathrm{ml}$ sedangkan standar EU adalah 3,75 $\log _{10} \mathrm{cfu} / \mathrm{ml}$. Kontaminasi Staphylococcus aureus pada susu segar penelitian ini kemungkinan disebabkan oleh pencemaran yang berasal dari lingkungan baik yang berasal dari hewan, manusia dan alat yang digunakan.

Sumber kontaminasi Staphylococcus aureus lainnya karena kambing perah mengalami penyakit mastitis subklinis (Cahyono et al. 2013). Infeksi intramamae yang dapat bersifat subklinis maupun klinis disebabkan oleh infeksi Staphylococcus aureus pada kambing perah. Kejadian mastitis subklinis kemungkinan tidak diketahui oleh peternak, karena kambing perah tidak memperlihatkan adanya pembengkakan ambing.

Nilai $a_{w}$ susu segar juga mem-pengaruhi pertumbuhan Staphylococcus aureus, a susu segar berkisar 0,850-0,941, sedangkan Staphylococcus aureus hanya membutuhkan $\mathrm{a}_{\mathrm{w}}$ minimum sebesar 0,86 (Rahayu dan
Nurwitri 2012), sehingga a $\mathrm{w}_{\mathrm{w}}$ susu tersebut cukup mendukung pertumbuhan dari bakteri Staphylococcus aureus.

Hasil pengujian salmonella $s p$. pada susu kambing segar baik pada pemerahan pagi dan sore menunjukkan tidak adanya kehadiran salmonella $s p$. Hal ini sudah sesuai dengan EC (1992) yang mensyaratkan bahwa susu segar tidak boleh memiliki kandungan salmonella sp. (negatif) karena salmonella sp. dapat menyebabkan foodborne disease berupa salmonellosis yang mengakibatkan penyakit tipus dan paratipus (Rahayu dan Nurwitri 2012). Pencemaran dan penyebaran infeksi danmikroorganisme salmonella sp.ini dapatdatang dari feses ternak.

\section{Berat jenis}

\section{Uji Fisik dan Kimia Susu kambing}

Berat jenis pada penelitian kambing ini memberikan pengaruh yang tidak nyata $(\mathrm{P}<0,05)$ pada waktu pemerahan (Tabel 3). Susu kambing pada pemerahan sore hari lebih tinggi $(1,032)$ dibandingkan susu kambing pemerahan pagi hari $(1,025)$. Terlihat bahwa terdapat perbedaan jumlah berat jenis antara susu pemerahan pagi dan susu pemerahan sore meskipun analisis ragam menunjukkan tidak berbeda nyata. Perbedaan nilai berat jenis tersebut disebabkan oleh kandungan total solid/bahan kering susu pada pemerahan sore lebih tinggi dibanding susu pagi. Hal ini sesuai dengan pendapat Ecles et al. (1984) yang menyatakan, faktor-faktor yang mempengaruhi perubahan berat jenis susu adalah faktor dari susu itu sendiri yang terdiri dari protein, lemak, laktosa, gas dan mineral dalam susu. Rataan berat jenis susu menunjukkan bahwa susu pemerahan sore hari sesuai dengan batas minimal Standar Nasional Indonesia (SNI 2011) yaitu 1,027 , sedangkan untuk susu pemerahan pagi hari tidak sesuai dengan SNI karena hanya sebesar 1,025. Menurut pendapat Edelstein (1988) menyatakan, berat jenis susu kambing bervariasi antara 1,026-1,042.

\section{Nilai pH}

Hasil analisis statistik waktu pemerahan memberikan pengaruh tidak nyata $(\mathrm{P}<0,05)$ terhadap nilai $\mathrm{pH}$ susu kambing pemerahan pagi dan pemerahan sore hari. Pada susu pemerahan pagi memperoleh hasil rata-rata yaitu 6,746 dan 6,614 pada susu pemerahan sore hari. Waktu pemerahan tidak memberikan pengaruh terhadap $\mathrm{pH}$ dari susu kambing. Nilai pH susu segar hasil penelitian sesuai dengan standar SNI yaitu berkisar 6,3-6,8, Perbedaan nilai pH pada susu kemungkinan disebabkan karena cemaran mikroba susu pagi lebih tinggi dibandingkan dengan susu sore (Tabel 2), hal ini sesuai dengan Swadayana et al. (2012) yang menyatakan bahwa cemaran mikroba pada susu setelah dapat mempengaruhi adanya perubahan $\mathrm{pH}$ susu.

\section{Aktivitas Air $\left(a_{w}\right)$}

Aktivitas air $\left(\mathrm{a}_{\mathrm{w}}\right)$ atau air bebas mampu membantu aktivitas pertumbuhan mikroba dan aktivitas bahan pangan, seperti susu. Analisis ragam menunjukkan bahwa waktu pemerahan susu pagi tidak berbeda nyata dengan pemerahan susu sore hari. Penelitian ini dilakukan pengukuran $\mathrm{a}_{\mathrm{w}}$ dan diperoleh nilai $\mathrm{a}_{\mathrm{w}}$ pada susu pemerahan pagi lebih besar 0,916 dan susu sore lebih kecil 0,896. $a_{w}$ susu pemerahan pagi lebih besar dapat disebabkan karena kelembaban udara pada pagi hari lebih tinggi dibanding sore hari (Tabel 2) sehingga pada saat pemerahan, terjadi penambahan kadar 
Tabel 3 Uji fisik dan kimia susu

\begin{tabular}{lcc}
\hline Kualitas susu & Susu Pagi & Susu Sore \\
\hline Berat Jenis & $1,025 \pm 0,001$ & $1,032 \pm 0,005$ \\
$\mathrm{pH}$ & $6,746 \pm 0,222$ & $6,669 \pm 0,100$ \\
Aw & $0,916 \pm 0,014$ & $0,895 \pm 0,046$ \\
BKTL (\%) & $7,74 \pm 0,34$ & $8,16 \pm 0,26$ \\
Lemak (\%) & $5,53 \pm 0,35$ & $7,83 \pm 1,77$ \\
Protein (\%) & $3,83 \pm 0,12$ & $3,97 \pm 0,12$ \\
Laktosa (\%) & $3,80 \pm 0,17$ & $4,00 \pm 0,17$ \\
\hline
\end{tabular}

Keterangan : Superskrip yang berbeda pada baris yang sama menunjukkan berbeda nyata pada taraf $5 \%(\mathrm{P}<0,05)$. BKTL : Bahan kering tanpa lemak

air secara langsung. Nilai $\mathrm{a}_{\mathrm{w}}$ sangat berkaitan erat dengan kualitas mikrobiologi susu segar. Nilai $a_{w}$ yang tinggi membuat susu lebih rentan dengan cemaran mikroba. Bakteri gram positif tumbuh pada $\mathrm{a}_{\mathrm{w}} 0,90$ sedangkan bakteri gram negatif tumbuh pada $a_{w} 0,93$ (Rahayu dan Nurwitri 2012). Susu pagi memiliki nilai $a_{w}(0,916)$ yang mendukung untuk pertumbuhan mikroba dibandingkan nilai $\mathrm{a}_{\mathrm{w}}$ susu sore $(0,895)$.

\section{Bahan kering tanpa lemak (BKTL)}

Analisis ragam menunjukkan BKTL susu pemerahan pagi $7,74 \%$ menunjukkan perbedaan yang tidak nyata terhadap susu pemerahan sore $8,16 \%(\mathrm{P}<0,05)$. Susu pemerahan sore hari sesuai dengan SNI No 3141.1 (2011), yaitu bahan kering tanpa lemak minimum 7,8\%, sedangkan untuk susu pemerahan pagi hari kurang layak karena menunjukkan angka kurang dari 7,74\%, meskipun tidak berbeda nyata namun nilai rata-rata menunjukkan adanya perbedaan jumlah dari susu pemerahan pagi dan susu pemerahan sore. Susu pemerahan sore hari memiliki kandungan bahan kering lebih tinggi $(8,16 \%)$ dibandingkan susu pemerahan pagi hari. Hal ini disebabkan oleh tingginya komposisi susu sore dibanding susu pagi.

\section{Lemak}

Hasil penelitian menunjukkan bahwa rata-rata kadar lemak susu pada pemerahan pagi diperoleh hasil yaitu $5,53 \%$ dan pada pemerahan sore 7,83\%. Analisa keragaman menunjukan bahwa kadar lemak susu susu pemerahan pagi dan susu pemerahan sore tidak berbeda nyata $(\mathrm{P}<0,05)$. Namun, meskipun tidak berbeda nyata terlihat adanya perbedaan nilai rata-rata susu pemerahan pagi dan pemerahan sore hari. Hal ini disebabkan interval waktu pemerahan yang dilakukan pada pagi hari lebih lama dibandingkan dengan sore hari yaitu dengan interval waktu 7 dan 17 jam yang menyebabkan lamanya ambing dalam keadaan kosong sehingga tekanan ambing menjadi rendah yang selanjutnya akan meningkatkan sekresi dalam ambing (Mardalena 2008).Menurut Budiwiyono et al. (1980) waktu pemerahan menghasilkan pengaruh yang sangat nyata terhadap kadar lemak susu dimana kadar lemak susu sore hari lebih tinggi dari pada pagi hari. Selain itu menurut Davendra dan Burns (1994) jenis pakan dapat mempengaruhi kualitas komposisi susu. Pakan konsetrat diberikan oleh peternak pada pagi hari, namun pakan tersebut baru akan tersintesis pada susu saat pemerahan sore hari, sehingga komposisi susu sore lebih baik dibandingkan dengan pagi hari.

Hasil penelitian kadar lemak susu pada pemerahan pagi hari sesuai dengan Standar Nasional Indonesia (2011), yaitu untuk susu segar minimum 2,8\%, sedangkan menurut Thai Agriculture Standar (2008) kadar lemak susu kambing untuk kelas premium minimum 4,0.

\section{Protein}

Analisis ragam menunjukkan bahwa waktu pemerahan memberikan perbedaan tidak nyata $(\mathrm{P}<0,05)$ terhadap kadar protein antara susu pemerahan pagi (lebih rendah) dan susu pemerahan sore hari (lebih tinggi). Meskipun tidak berbeda nyata, kadar protein pemerahan pagi lebih rendah daripada pemerahan sore hari, Perbedaan itu dikarenakan adanya perbedaan jenis pakan yang diberikan dan interval waktu pemerahan yang berbeda. Menurut Zurriyati et al. (2011), kualitas pakan yang baik pada ternak cenderung akan meningkatkan kandungan solid non fat dalam susu. Kualitas kombinasi dari pakan hijauan yang diimbangi dengan konsentrat, ampas tahu, dll akan menghasilkan kandungan protein yang lebih baik dibandingkan dengan pakan yang hanya diberikan pakan hijauan saja. Protein adalah salah satu dari komponen solid non fat (bahan kering tanpa lemak).

Rataan kadar protein menunjukkan bahwa untuk susu pemerahan pagi dan sore hari sesuai dengan Standar Nasional Indonesia (2011), yaitu dengan batas minimum 2,8\% dan Thai Agriculture Standard (2008) yaitu 3,7\% untuk kelas premium, kelas sedang 3,4-3,7\%, dan kelas standar 3,1-3,4\%.

\section{Laktosa}

Laktosa merupakan salah satu kandungan gizi penting yang terdapat dalam susu. Hasil analisis statistik tidak menunjukkan pengaruh nyata terhadap kadar laktosa. Susu pemerahan pagi memperoleh hasil rata-rata 3,80\% dan susu pemerahan sore sebesar 4,00\%. Susu pemerahan sore memiliki kadar laktosa lebih besar karena lebih banyaknya pakan hijauan yang dikonsumsi ternak kambing. Pada penelitian ini pakan hijauan yang diberikan pagi dan sore hari, namun sebelum diberi pakan hijauan terlebih dahulu diberikan pakan konsentrat pada pagi hari.

\section{KESIMPULAN}

Berdasarkan hasil penelitian dapat disimpulkan bahwa susu kambing segar hasil pemerahan sore memiliki sifat fisik, kimia dan mikrobiologi yang lebih baik dibanding susu kambing segar hasil pemerahan pagi hari. Kedua susu pemerahan pagi dan sore sesuai dengan SNI 3141.1 tahun 2011. Secara keseluruhan susu kambing yang diperoleh dari peternakan Cangkurawok Dramaga, Bogor masih layak untuk dikonsumsi jika diolah terlebih dahulu dengan perlakuan pemanasan untuk membunuh Escherichia coli dan Staphylococcus aureus yang terkandung di dalam susu tersebut.

\section{Saran}

Perlu dilakukan penelitian lebih lanjut mengenai pengaruh kondisi hygiene peternak dan sanitasi kandang terhadap jumlah cemaran mikroba pada susu kambing. 


\section{DAFTAR PUSTAKA}

Budiwiyono, D., M. Sabrani, D. Lubis dan H. Setiyanto. 1980. Evaluasi kualitas susu pemerahan pagi dan sore hari di Daerah Pengalengan dan Lembang. Bull. Bandung (ID): LPP. $25: 24$.

[BSN] Badan Standarisasi Nasional. 2011. No. SNI 01-3141-2011. Susu Segar. Jakarta (ID): Badan Standarisasi Nasional.

[BSN] Badan Standarisasi Nasional. 2008. No. SNI 28972008. Metode pengujian cemaran mikroba dalam daging, telur dan susu, serta hasil olahannya. Jakarta (ID) : Badan Standarisasi Nasional.

Cahyono, D., C.P. Masdiana \& ES. Manik. 2013. Kajian kualitas mikrobiologis (total plate count (tpc), Enterobacteriaceae dan Staphylococcus aureus) susu sapi segar di kecamatan krucil kabupaten probolinggo. Jurnal Ilmu dan Teknologi Hasil Ternak, April 2013, Hal 1-8 Vol. 8, No. 1 ISSN : 1978 - 0303

Davendra. C., \& M. Burns. 1994. Produksi Kambing di Daerah Tropis. Terjemahan : IDK Harya Putra. Bandung (ID): ITB Press.

Eckles, C.H, W.R. Corm dan H. macy. 1984. Milk and Milk product 4th. The Mac Graw Hill Publisher Inc, denvile Ikkinois.

Edelstein, D. 1988. Composition of Milk. Dalam : Cross H.R dan Overby A.J. Meat Science, Milk Science and Technology. Illinois (US): Interstate Publishing Inc.

European Council (EC). 1992. EC Directive 92/46/EEC of 16 June 1992 laying down the health rules for the production and placing on the market of raw milk, heattreated milk and milk-based products. Luxembourg.

Food \& Drug Administration (FDA). 2001. Bacteriological Analytical Manual. US (US): U.S. Food \& Drug Administration.

Gaman, P.M., Sherrington KB. 1992. Ilmu Pangan, Pengantar Ilmu Pangan, Nutrisi, dan Mikrobiologi. Gardjito M, penerjemah; Kasmidjo RB editor. Yogyakarta: Gadjah Mada Univ Pr. Terjemahan dari: The Science of Food, an Introduction to Food Science, Nutrition and Microbiology.

Mardalena. 2008. Pengaruh Waktu Pemerahan dan Tingkat Laktasi terhadap Kualitas Susu Sapi Perah Peranakan Fries Holstein. Jurnal Ilmiah Ilmu-Ilmu Peternakan. 2008. Vol. XI. No.3.

Mattjik, A. \& S.I. Made. 2013. Perancangan Percobaan. Institut Pertanian Bogor-(IPB) Press, Bogor.

Rahayu, W.P., \& C.C. Nurwitri. 2012. Mikrobiologi Pangan. Institut Pertanian Bogor-(IPB) Press, Bogor.
Swadayana, P., Sambodho, \& Budiarti. 2012. Total bakteri dan ph susu akibat lama waktu diping puting kambing peranakan ettawa laktasi. Animal Agricultural Journal, Vol. 1. No. 1, 2012, p $12-21$

Sudono, A., I.K. Abdulgani. \& H. Nadjib. 1989. Diktat Ilmu Produksi Ternak Perah. Jurusan Ilmu Produksi Ternak, Fakultas Peternakan. Bogor (ID): Institut Pertanian Bogor.

Thai Agricultural Standard. TAS 6006-2008. Raw Goat Milk. National Bureau of Agricultural Commodity and Food Standards, Ministry of Agriculture and Cooperatives. ICS 67.100.01. Published in the Royal Gaze tte Vol. 125 Section 139 D. Thailand.

Vimont, A., C.V. Rozand, \& M.L.D. Muller. 2006. Isolation of Escherichia coli O157:H7 and Non O157 STEC in Different Matrices: Review of The Most Commonly UseEnrichment Protocols. Lett. Appl. Microbiol. (42): 102108 .

Zurriyati Y., R.R. Noor \& R.R.A. Maheswari. 2011. Analisis molekuler genotipe kappa kasein ( $\kappa$ kasein) dan komposisi susu kambing Peranakan Etawah, Saanen dan Persilangannya. Bogor (ID): Jurnal Ilmu Ternak dan Veteriner. 16(1) : 61-70. 